\title{
CULTURA, HOLOCAUSTUL ȘI ANTISEMITISMUL ÎN TIMPUL TOTALITARISMULUI
}

\section{Florian Olteanu}

The article revealsthe main liaisons between dictatures and the antisemitism and the Holocaust. Totalitarian regimes tried to make dificult the life of the Jews communities form the European states.

Key words: Antisemitism, Holocaust, tyranny, dictature, culture

$\mathrm{Ca}$ orice regim, totalitarismul, cunoscut sub noțiunile de tiranie şi dictatură izvorăşte din Antichitatea clasică, europeană, adică din perioada în care s-a făurit sistemul politic european.

Tirania și dictatura, ca forme ale totalitarismului nu au rămas încremenite în istorie, ci, au evoluat, completând modelul politic al totalitarismului păstrând aproape toate caracteristicile antice: dorinţa de identificare cu trecutul, semeția, teama de conspirații, teroarea, ambiția de dominare, victoriile sportive, cooperarea, copierea modelului, construcțiile monumentale, populismul și simbolistica. Ideologiile extremiste, fie ele de dreapta sau de stânga au găsit în dictatură un regim menit să asigure dominația și existența sistemului. Ca și în Antichitate, influența externă, degradarea economică, dorința de ridicare prin orice mijloace făceau ca regimurile autoritare să atragă poporul.

Cum venirea dictatorului sau a tiranului era învăluită în legendă și înlăturarea lui avea aceeași conotație. $\mathrm{O}$ caracteristică a regimului totalitar este puterea discreționară a șefului regimului.

Locul Spartei și al Imperiului Persan a fost luat în anii contemporaneităţii de Germania, Italia și Uniunea Sovietică și de China. Ca și atunci, Orientul i-a fascinat pe europeni. Absolutismul și despotismul nu au fost însă compatibile cu spiritul european. Moștenirea instituțiilor, a dreptului au făcut ca Europa să respingă aceste regimuri contemporane, care au avut soarta celor din Antichitate. Tot în Orient, Egiptul, Babilonul, Imperiul Persan au fost civilizațiile care au promovat ideologii extremiste menite să îii extermine pe evrei. Orientul este cel în care s-au pus bazele Shoah-ului (Holocaustului).

Evul mediu românesc s-a manifestat drept o confruntare a creștinismului ortodox cu romano-catoli- cismul, protestantismul și islamul. Relaţiile cu evreii au evoluat pe filiera bizantină și mai târziu otomană, spațiul românesc fiind unul al toleranței, aici stabilindu-se evreii askhenazi și evrei sefarzi. Evreii pământeni au locuit aici, mulți dintre ei neavând statut de supuși străini, fiind incluşi în masa locuitorilor români. Când s-a pus problema acordării cetățeniei, a fost o luptă îndelugată începută în secolul al XIX-lea și sfârșită abia în 1919, când evreii pământeni au primit în bloc cetățenia română.

Pe teritoriul României s-a dezvoltat curentul sionist, acela al reîntemeierii Israelului, al întoarcerii în Eretz Israel (oraşul-port Galaţi a fost cel mai important centru al sionismului din România și unul dintre cele mai importante din Europa).

Democrația şi totalitarismul tiranic sau dictatorial și-au dat mâna, acolo unde interesele au cerut-o. Chiar o democrație cum e cea din Statele Unite ale Americii nu a respins ab initio colaborarea cu tiranii sau cu dictatorii, în caz că avea nevoie de un pion important, dar nu a perpetuat colaborarea.

În ceea ce privește cele două noțiuni, ele sunt folosite pentru a desemna același regim. Dictatura este noțiunea folosită pentru a desemna din punct de vedere juridic un regim totalitar. Tirania este noțiunea peiorativă prin care se critică sistemul politic. Modelul dictaturii şi al tiraniei, ca elemente de bază ale totalitarismului, este unul european, greco-latin. Putem să-l considerăm ca un substrat politic. Un strat politic este cel ideologic. Revoluţia Franceză, inventatoarea conceptelor de „dreapta” sau de „stânga” a oferit motorul ideologic, exploatat de nazism, fascism și comunism.

Mai putem vorbi de un superstrat, de influență latino-americană, africană și asiatică. Aceste zone, autoritare prin excelenţă au folosit identificarea per- 
sonajelor cu lideri autohtoni şi cu tradiții care să le confere diferențe de abordare. Antichitatea clasică a oferit modeul revoluției ca act prin care tiranul sau dictatorul sunt înlăturați. Fie că e precedată de o lovitură de stat, fie că e un aspect al său, revoluția este motorul progresului. Ea este cea care rupe ritmul, face să fie recuperat decalajul politic. Totuși, dacă democrația este cea care se ridică împotriva tiraniei şi dictaturii, sau îi urmează firesc, dacă este prost gestionată, poate degenera în dictatură. Este un proces ciclic pe care doar respectarea legii, a instituţiilor şi deciziilor acestora pot să-1 asigure. Secretul democrației este acela, că deși e imperfectă, este cea mai bună formă politică inventată de către umanitate, pe parcursul evoluției acesteia.

Au trecut 28 de ani de la momentul în care Nicolae Ceaușescu a început să vadă sfârșitul regimului său, odată cu vuietul din Piața Palatului din 21 decemrie 1989. Suntem la 28 de ani de la revoluție. În decembrie 1989 se terminau 24 de ani de regim ceauşist. În august 1965, românii au sperat că Nicolae Ceaușescu va încerca să promoveze un comunism național. Destinul politic al lui Nicolae Ceauşescu a fost influenţat de atitudinea sa din 1968, când a condamnat agresiunea Pactului de la Varșovia asupra Cehoslovaciei. Demersurile fuseseră făcute de Gheorghiu Dej, cu a sa Declarație de Independență, rostită cu ocazia conflictului ideologic sovietochinez. Moartea lui Dej, suspectă și neelucidată, îi lăsa lui Ceaușescu avantajul de a consolida și prestigiul deblocării relațiilor chino-americane, prin canalul diplomatic de la București. Faptul că până la declanșarea revoluției culturale, după vizitele în Coreea de Nord și China, Nicolae Ceauşescu avusese întrevederi cu liderii importanți ai Franței, Marii Britanii, SUA, China, îl făcea să se țină seama de el. Celelalte succese, ca detensionarea situației conflictuale dintre Israel și vecinii arabi, tratativele cu Gaddafi, Saddam Hussein, Yasser Arafat, cooperarea cu statele africane și latino-americane, pe bază de afinităţi doctrinare, făcea ca România să fie un vector de negociere.

Dar Ceaușescu s-a oprit. De undeva din resorturile minții sale de tânăr plecat dintr-un sat din Muntenia, i s-a părut că el făcuse destul pentru prestigiul țării. Spera că având relaţii stabilite, putea să asigure supraviețuirea României, ca a unei familii, care să producă strict ce avea nevoie pentru consum, să facă economii, marea parte a producției să meargă la export. Faptul că în anii 80 se apropia scadența împrumuturilor pentru modernizare contractate în anii ' 70 , Ceaușescu a dorit să scape de acestea, pentru a economisi valuta, uitând că mersul economiei nu va mai fi constant, datorită faptului că trebuia să se investească în tehnologie. Cum România nu putea produce tot, sau dacă producea o făcea prost (Gorbaciov spunea că URSS importa din România doar în virtutea relațiilor de bloc socialist, 90 \% fiind aruncat, iar Germania federală importa echipamente din fier și oțel doar că topirea acestora costa mai puțin decât extragerea şi prelucrarea minereului n.a.), trebuia investit.

Ceaușescu a dorit să facă pentru țara sa, ceea ce tatăl său, împătimit consumator de alcool nu făcuse pentru familia lui. Se dorea, și propaganda îi inoculase pe deplin asta, un fel de „tătuc” al națiunii, un om care să decidă totul. Ideea cu blocurile care au bucătăria la parter, din Coreea de Nord 1-a impresionat. A mers mai departe, construind circurile foamei, uriașe cantine, în care oamenii muncii să uite de grija preparării hranei. Astfel, banii, comerțul, produsele încetau să mai existe, în afara controlului de stat. Achitarea datoriei din 1989, pe fondul acutei crize, a grăbit sfârșitul său, mai ales că toți foștii colaboratori din Vest se desolidarizaseră de acesta și deja luptau să preia piețele pe care se desfășura activitatea României. Înconjurat de oameni fideli, sub nivelul mediocrităţii ca inteligență și viziune, suspicios în permanență că poate fi sabotat de Moscova, Nicolae Ceauşescu a greșit fatal în decembrie 1989. Prost informat, sau neluând în seamă situația, el a efectuat o vizită de stat în Iran, exact când la Timișoara începuseră violențele de stradă. În 21 decembrie 1989, dictatorul a luat o altă decizie fatală, condamnarea acțiunilor ,antiromânești” pornind de la modelul acțiunii din 1968, când lumea 1-a văzut ca pe un campion al luptei pentru pace. Manipularea a funcționat perfect, Ceauşescu nedându-și seama că acum lupta contra propriului său popor. Mitingul a fost un fiasco total, pentru că revoluţionarii au 
deturnat acțiunea spre revoltă deschisă. Acțiunea lui Nicolae Ceaușescu a fost aceea de ,a stinge focul cu gaz", ca să folosim o expresie populară, iar sfârșitul a venit doar la câteva zile. Dar oare ce avem acum? Revoluționarii sunt azi victimele celor care, grație eforturilor lor au ajuns la putere. Soarta revoluţionarilor a fost crudă în toate sistemele. Napoleon i-a împrăștiat cu tunurile, în 1795, Stalin i-a lichidat pe toți, guvernele post-decembriste își bat joc la propriu, deși au avut rolul esențial în grevele ce au dus la căderea guvernului Ungureanu în Parlament. Asta nu înseamnă că, pe lângă faptul că am avut terorism fără teroriști și alte ciudățenii, nu am avut și o fabrică de certificate de revoluţionari.

Sincer, la 28 de ani de la momentul 21 decembrie 1989, considerăm că istoricii mai au de investigat despre ce s-a întâmplat atunci. Totuși, nu atributul lor e necesar ci respectul factorilor responsabili faţă de cei ce au luptat într-adevăr pentru ,raţia de libertate" din 1989.

Napoleon a impulsionat modernizarea Europei, prin legile, prin faptul că armatele sale au adus cu ele ideile Revoluţiei Franceze. A fost totuşi un adversar al absolutismului catolic, în timpul său, Papa fiind exilat, iar Roma devenind Regat sub fiul său minor, Napoleon al II-lea. Mult timp, Napoleon şi-a dorit să elibereze Estul, inclusiv Locurile Sfinte ca Ierusalimul. Datorită lipsei unei reguli de succesiune, toți împărații romani au ajuns, de multe ori, prin uzurpare. Aici vom vedea momentul în care iudeii au fost ocupaţi de romani, momentul izgonirii lor din Ierusalimul dărâmat, al începutului diasporei, deoarece, încă de atunci evreii și-au dorit întoarcerea în Eretz Israel, principiu de bază al Sionismului.

Evreii au fost persecutaţi de către catolici, fiind consideraţi eretici. Numeorşi evrei au fost nevoiţi să plece din Spania, spre Est, inclusiv în spațiul românesc, ei fiind prigoniți în același timp cu adepții creștinismului protestant. Religia și cultra comună, păstrată pe ascuns i-a ținut însă, laolaltă pe evrei.

Carol al II-lea a dorit să-și subordoneze Mișcarea Legionară, dar, nereuşind 1-a lichidat pe șeful ei Corneliu Zelea Codreanu. A înființat primele organizații de tineret, "străjerii", care l-au inspirat şi pe Ceauşescu în organizarea "șoimilor patriei” și “pionierilor". Şantierele tineretului, inaugurate de Ceaușescu semănau cu taberele legionare, diferind faptul că sub Ceauşescu nu se organizau rugăciuni.

Legionarii supralicitau fermentul creștin și național, pornind de la ideologia extremistă a lui A.C.Cuza, evreii fiind considerați un "dușman" care trebuia eliminat.

Preferința lui Ion Antonescu spre extremismul de dreapa e vizibilă și din cauza apropierii lui de personalități cu astfel de vederi ca Octavian Goga, A.C.Cuza, ocupând chiar demnități ministeriale în guvernele marionetă ale lui Carol al II-lea. Anul 1937 marchează începutul promovării legislației antisemite, odată cu faptul că Partidul Totul Pentru T,ară, paravanul politic al legionarilor obținuse la alegerile parlamentare din 1937 a treia poziție. Atunci liberalii, deși ieșiţi pe primul loc, nu au reușit să obțină $41 \%$ pentru a devenii beneficiarii "primei electorale" de $10 \%$, o soluție interesantă în crearea une majorităţi solide în Parlament. Regele Carol al II-lea a oferit guvernarea extremei drepte reprezentate de Octavian Goga și A.C.Cuza.

În perioada septembrie 1940-ianuarie 1941, guvernarea legionaro-antonesciană a dezlănțuit prigoana împotriva evreilor, pe care atât Horia Sima, urmaşul politic al lui Codreanu cât și Ion Antonescu îi considerau adepți ai comunismului, agenți ai bolșevismului. Au apărut pogromurile, regimul antonescian a trecut la deportarea evreilor în Transnistria. Sima şi apoi Antonescu au pornit de la originea evreiască a multor activiști comuniști (deși printre comunişti erau foarte mulți români, bulgari, maghiari, ucrainieni) pentru a crea o generalizare periculoasă și incorectă istoric -"orice evreu este comunist și orice comunist este evreu" .

Prigoanei antisemite le-au căzut victime numeroși evrei români, mulți dintre ei decorați pentru bravură în anii primului război mondial, ori cu merite deosebite la realizarea Marii Uniri. Începând cu 1944, dar mai ales după 1953, deci odată cu dispariția lui Stalin, Gheorghiu Dej a început epurarea activiștilor de origine evreiască, maghiară etc acuzându-i de deviaţionism de dreapta, în realitate aceștia susținând linia politică a Moscovei, în dauna comunismului naţional: Ana Pauker, Teohari Georgescu, Vasile Luka. 
Stalin este creatorul cultului personalităţii lui Lenin în Uniunea Sovietică, pentru a putea apoi să-1 impună pe al său. A ordonat îmbălsămarea trupului fondatorului statului sovietic şi depunerea sa într-un mausoleu. Mai multe orașe din URSS și din statele satelit au primit numele lui Stalin, și Lenin, în ciuda criticilor Nadejdei Krupskaia, lui Lev Troțki.

Stalin a creat un regim care i-a purtat numele, care a ridicat țara, dar s-a impus prin cruzime, fapt ce a făcut ca denunțarea stalinismului să aibă loc imediat sub succesorul său, Nikita Hrușciov în februarie 1956. În "Raportul secret", Despre cultul personalității și consecințele lui, ținut în cadrul sesiunii închise a celui de-al XX-lea Congres al Partidului Comunist al Uniunii Sovietice, Hrușciov a prezentat "violările normelor leniniste de legalitate", dar asta nu însemna neapărat o destindere. Este cunoscută duritatea reprimării revoluției ungare din 1956, o consecință firească a începutului destalinizării, când s-a încercat o îndepărtare a staliniștilor maghiari. În momentul în care Stalin a ajuns să dețină controlul absolut asupra puterii sovietice, acesta a dezlănţuit un teribil proces de îndepărtare a apropiaților săi, mergând până la prietenii din copilărie.

"Mașinăria infernală" creată de Stalin și protejaţii săi, Beria, Ejov, Iagoda a făcut ca numărul celor care au ajuns în Gulag să fie de circa 23 milioane. Marea lor majoritate erau oameni simpli, însă teroarea ajunsese până la vârfurile partidului, armatei, vieții publice etc.

Procesele politice aveau adeseori și momente, pe care nu le puten numi "vesele", datorită gravității lor extreme. De exemplu, un acuzat de spionaj a spus la un interogatoriu că nu se putea numi întâlni în Copenhaga, la hotelul indicat în rechizitoriu, pentru că acesta era în Oslo. Stalin, când a auzit de această greșeală a NKVD-ului ar fi izbucnit isteric: "De ce dracu n-aţi scris că s-au întâlnit la gară? Gările rămân întotdeauna pe loc".

De furia lui Stalin n-au scăpat nici apropiaţii săi, prieteni din copilărie, unul dintre aceștia fiindcă îndrăznise să-i spună lui Stalin să nu-i îndepărteze pe foștii bolșevici sfârșind împuşcat ca spion american. Unul dintre oamenii săi de încredere Pauker, cel care se ocupa de toate detaliile prezenţelor publice ale lui Stalin, de pregătirea meselor și a hainelor de interior şi care chiar îl distra de minune pe Stalin cu anecdote a fost și el condamnat și executat ca dușman al poporului.Printre numele grele care au căzut a fost inclusiv Iagoda, cel care îl ajutase pe Stalin în instrumentarea proceselor politice din anii 30. În timpul războiului, cel mai răsunător caz de îndepărtare a fost acela al mareșalului Tuhacevski. Sunt mulți istorici care au opinat că germanii, dorind să-1 îndepărteze din Armata Roșie au fabricat un dosar pe care 1-au "scăpat" sovieticilor, mareșalul sfârșind în fața plutonului de execuție, ca trădător.Cercetări recente tind să redefinească spectrul eliminării lui Tuhacevski, în sensul că acesta s-ar fi aflat într-un cerc restrâns care știa un secret teribil, împărtăşit prin jurământ aspru, acela că Stalin fusese agent al "Okhranei” țariste, trădându-și colegii de luptă.

În "Arhiperlagul Gulag”, Aleksandr Soljenițîn povestea cum responsabilul căminului cultural care nepriminid ajutor să transporte bustul oficial al tovarășului Stalin a găsit ingenioasa soluție să-1 ducă în spinare, înfășurând cureaua în jurul gâtului "generalissimului", soluţie care i-a atras condamnarea în baza temutului articol 58, care pedepsea trădarea de țară. Atunci când cel căzut în dizgrație era prea cunoscut ca să poată să fie adus în fața unui proces public, cum a fost cazul lui Kirov, Stalin a fost capabil să însceneze un atentat, Leonid Nikolaev, împuşcându-l cu un pistol, după ce paza 1-a oprit iniţial și 1-a reținut pentru câteva ore. Gestul lui Stalin, de a săruta truplul lui Kirov în sicriu, în noaptea în care acesta a făcut de gardă la catafalc, a fost văzut drept "sărutul lui Iuda", dat lui Hristos, dat fiind trecutul de seminarist al lui Stalin.

Pe Troțki, părintele Armatei Roșii, inițial exilat, brațul lui Stalin 1-a urmărit pretutindeni, din Kasahstan, până în Mexic, unde acesta a fost în cele din urmă asasinat, de către Ramon Mercader, în 1940. Treptat, din pozele de grup oficiale, prin retuşare, dispăreau fețele celor care căzuseră în dizgrație: Zinoviev, Kamenev, Buharin.

Evreii, în Eretz Israel, au dezvoltat ideea comunității în care membrii sunt egali pe deplin. 
Caeste comunități ale egalilor, numite "kibbutzuri" au fost baza constituirii Israelului actual, ele continuând să existe și astăzi. Stalin, iniţial, a dorit promovarea comunismului prin "kibbutz-uri", dar a abandonat ideea pentru că aceste comunități nu înțelegeau să se supună niciunei autorități ci având o relaţie de egalitate cu statul, ele precedând statul Israel. Astfel, Stalin a abandonat ideea susţinerii "kibbutz-urilor". Majoritatea acestora fuseseră înfiinţate de evrei originari din Belarus, Ucraina, Rusia, zone din care Stalin deportase populaţii întregi pe care le considera dușmane ale noii ordini comuniste. Așadar, "kibbutz-urile", "moshav-urile", un fel de cooperative cu un statut inferior, forme de organizare "comunistă" au devenit indezirabile lui Stalin, liderul comuniștilor sovietici. El a creat în schimb "colhozuri", "sovhozuri", structuri cooperatiste organizate prin forță. După model stalinist au apărut "GAC-urile", "CAP-urile" și "IAS-urile" din România și alte state ale blocului socialist.

Un alt aspect al revoluţiei culturale îl constituie relația cu biserica. Mussolini a restabilit relațiile cu Statul Papal în 1929, punând capăt întreruperii care data încă din 1871. Acest fapt 1-a făcut popular în rândurile clerului catolic și ale italienilor în general, dar relaţiile au rămas destul de tensionate. Față de islam, Mussolini a avut o atitudine relativ binevoitoare, ceea ce 1-a făcut popular în rândurile musulmanilor libieni și africani.Relația cu evreii s-a degradat, de la o "tolerare" iniţială, spre un Holocaust comandat la dorința lui Hitler care își condiționa sprijinul tot mai mare pentru Italia.

Stalin, fost seminarist în confesiunea ortodoxă a prigonit Biserica. Doar în timpul războiului a avut o atitudine mai conciliantă, restaurând în 1943 Patriarhia de Moscova, desfiinţată în anii 20. Şi el i-a încurajat pe musulmanii din Asia Centrală, în măsura în care aceștia luptau sub egida unor mișcări comuniste. Stalin s-a dezlănţuit contra evreilor, mai ales în timpul "complotului halatelor albe", când i-a acuzat pe cei mai de seamă medici (mulţi dintre ei de origine evreiască) de faptul că 1 -ar fi lichidat pe Gorki, Kuibîșev sau Sverdlov la presiunile "imperialiștilor" occidentali. Hitler, creatorul unei ,noi ordini” se considera suficient de puternic încât ideologia sa să țină loc de religie. E interesant faptul că la un moment dat Hitler a făcut unele declarații de simpatie față de islam, mai ales față de ideea de „război sfânt”. Simpatiile sale față de islam veneau și din cauza conflictului dintre evrei şi musulmani, dorind cumva să asmută o altă religie contra evreilor. Hitler este cel care a promovat cel mai dur antisemitism, este cel care a pus bazele Holocaustului contemporan, cel mai îngrozitor din întreaga epocă. După numeroase pogromuri până în 1941, din acel an Germania nazistă a introdus ideea exterminării evreilor în lagăre de concentrare, ca Dachau, Bergen-Belsen, Sobibor, Auschwitz-Birkenau, Treblinka etc. În ianuarie 1942, Adolf Eichmann a implementat la Conferința de la Wannsee ideea "soluției finale". Trebuie amintite și "experimentele" lui Josef Mengele, în fapt acțiuni îngrozitoare care au provocat moartea a mii de deținuţi în scopuri așa-zis științifice. A apărut apoi chiar planul deportării evreilor pe insula Madagascar. Nicolae Ceaușescu a încercat să izoleze elita comunistă de biserică, dar s-a folosit de aceasta să controleze mai bine viaţa românilor. Soția sa, Elena Ceauşescu a dezvoltat o aversiune contra evreilor, creată, în special în perioada tinereții sale, în anii interbelici. Totuşi, relațiile lui Nicolae Ceauşescu cu statul Israel au fost dintre cele mai bune, el dorind să fie un pacificator în relația cu palestinienii, sirienii.

Fidel Castro a încurajat confesiunea catolică, dar și manifestările unei credințe populare inspirate de practicile sclavilor aduşi de peste ocean în timpul colonialismului. Liderii latino-americani ca Augusto Pinochet și Salvador Allende respectau valorile catolicismului, majoritar în statele lor, dar nu puteau împiedica existența credințelor urmașilor vechilor populaţii amerindiene.

Muammar Gaddafi și Saddam Hussein și-au construit regimul respectând valorile islamice, pe care le aşezau la temelia regimurilor politice conduse de ei. Orice dictator a fost preocupat atât de biografia oficială, cât și de propria sa imagine. Mussolini fusese un învățător, atras de gazetăria socialistă şi de concepțiile lui Vilfredo Pareto, dezvoltate în ceea ce avea să se numească corporatismul italian. Stalin era un dictator care citea foarte mult. Avea 
obiceiul să facă adnotări. Fusese un elev bun la seminar, datorită faptului că îsi respectase mama pe Ecaterina Geladze, care a făcut eforturi mari pentru a-l susține. Hitler avusese o singură pasiune, pictura. Odată refuzat, la admiterea la Viena, a făcut tot ce i-a stat în puteri să se impună ca un expert în materie. A organizat chiar o "expoziție de artă decadentă", sperând că germanii vor denigra în public arta de până atunci, așteptând noua artă. Efectul a fost contrar, germanii înghesuindu-se să vadă pentru ultima oară opere care urmau să fie scoase pentru mulți ani din circuitul public. Ideile lui Hitler în materie de pictură au fost contestate chiar de apropiați, de vreme ce toți naziștii de frunte, cu Goring în capul listei au încercat să fure opere de artă din Franța și celelalte state ocupate, pentru a-și face muzee private.

Tot după vizitele din Coreea de Nord și China, Nicolae Ceaușescu a impus un cult al personalității deșănțat, intitulându-se „Nicolae Ceaușescu, secretar general al Partidului Comunist Român, președintele Republicii Socialiste România, comandant suprem al forțelor armate". Foarte des, presa folosea apelativele ,genialul cârmaci”, „,cel mai iubit fiu al poporului român”, ,personalitate excepțională a lumii contemporane”, „luptător pentru cauza dreptății și păcii, și socialismului”, ,geniul Carpaţilor”, „marele conducător”.

După ce a cooptat-o pe Elena Ceauşescu în conducerea partidului și statului, acesteia i s-a construit o biografie știinţifică de excepție, fiind numită „savant de renume mondial” și „mamă iubitoare” a poporului. Grație eforturilor Securității, Elena Ceauşescu primise mai multe titluri de Doctor Honoris Causa la diverse universități din lume. După obținerea unui doctorat în chimie, Elena Ceaușescu, a devenit membră a Academiei Române.În 1974, Nicolae Ceaușescu a creat funcția de Președinte al Republicii, fiind învestit cu sceptru, proiectat de mai mulți specialiști. Pictorul Salvador Dali, un excentric, i-a trimis dictatorului o telegramă de felicitare, publicată în presa centrală.

Odată ajunși la vârful ierarhiei, dictatorii își făuresc cu ajutorul anturajului o biografie retușată, care ajungea să înlocuiască mai bine de 75 \% din viaţa lor reală. Totodată, dictatorii gustă manipularea propriilor lor servicii. Cazul cel mai cunoscut îl oferă Ion Mihai Pacepa în "Orizonturi Roșii”.

Când a vizitat, America, la invitația președintelui Gerald Ford, Ceaușescu a exclamat, la capătul unei vizite: "Băieții tăi au lucrat bine, Pacepa"! Elena Ceaușescu a exclamat nemulțumită că serviciile nu făcuseră nimic, personalitatea lui Ceaușescu fiind cea care "vrăjește". Tot Pacepa afirma că Nicolae Ceaușescu alegea să vorbească pe ascuns cu el, în timp ce funcționa un casetofon care reda vocea înregistrată a unei alte discuţii. Nicolae şi Elena Ceauşescu se temeau de evrei, iar originea evreiască a unor activişti din garda lui Dej a determinat îndepărtarea lor din cercurile înalte ale puterii comuniste.

Dacă lui Saddam Hussein i se crease o biografie oficială, în care era considerat descendent al lui Nabucodonosor II, lui Ceaușescu, câțiva politruci se grăbiseră să-i facă un cadou, în sensul că una din descoperirile de hominizi din Oltenia (Valea Dîrjovului, Bugiulești) avea să se numească Homo Scornicensis, de la numele satului natal al lui Ceaușescu.

Nicolae Ceaușescu era pasionat de vânătoare, de jocul de șah, de petreceri. Copilăria sa în Scornicești se terminase prea repede, aşa că plecând spre București, el visase să locuiască în case mari unde să petreacă, asemeni boierilor din satele Olteniei.

Hitler se relaxa la reședința sa de la munte, din Berchtesgarden, undeva în Bavaria, Stalin mergea pe malul Mării Negre, la Soci, în timp ce Nicolae Ceauşescu prefera să se relaxeze la mare, la munte, sau pe domeniile de vânătoare.

În ceea ce privește fobiile, Stalin se temea de otrăvire, Hitler de orie acțiune de trădare. Ceaușescu se temea de boli, astfel că servirea mesei se făcea în vase desigiliate, mâncarea era adusă în containere sigilate, orice membru al personalului care se tăia la deget sau avea guturai fiind trimis în concediu medical. Hitler a dorit să dea Olimpiadei din 1936 de la Berlin şi de la Garmischpartenkirchen imaginea unui triumf al arienilor. L-a contrazis puțin Jesse Owens, atletul de culoare care a luat patru medalii de aur la atletism. Nervos, Hitler, de patru ori s-a văzut nevoit să plece de la tribună. 
Mussolini s-a ocupat personal ca Italia să câştige două cupe mondiale la fotbal, din totalul de patru câştigate până în prezent.

Nicolae Ceaușescu a dat o atenție sporită Olimpiadelor. Triumful Nadiei Comăneci, de la Montreal din 1976 a fost victoria unui sistem al educaţiei, Nadia devenind ea însăși un simbol, până la fuga acesteia, din 1989.

În 1980, la Moscova, Nicolae Ceauşescu a protestat față de "nedreptatea" arbitrelor la gimnastică, delegația română fiind retrasă. Patru ani mai târziu, când, la Los Angeles, Nicolae Ceaușescu a autorizat participarea olimpicilor români, România fiind singura țară socialistă participantă (locul 3 pe medalii), el a primit distincția "Cercurile Olimpice de Platină", fiind singurul lider comunist care a avut această demnitate.

La capitolul fotbal, Nicolae Ceaușescu a dorit să facă o echipă a Scorniceștiului. Chiar dacă în epocă era cunoscută practica aranjamentelor între echipele Armatei (Steaua) şi Miliţiei (Dinamo), Nicolae Ceauşescu a vrut să realizeze o echipă, Victoria Socialismului (condusă de Mitică Dragomir), care să devină fanion. În 1986, după un meci spectaculos, Steaua obținuse Cupa Campionilor Europeni, la Sevilla, în faţa Barcelonei. Meritul fusese al lui Valentin Ceaușescu, care, la propriu, contrar oricăror reglementări, s-a jucat de-a "președintele de club". $\mathrm{Cu}$ sprijinul Securităţii, el a reuşit să perfecteze transferurile, astfel încât parcursul Stelei, în acel an, să fie fără pată. Până în 1989, Steaua a mai jucat o finală, pierzând în fața lui AC Milan. Toate sporturile din România, mai puțin cele olimpice de iarnă (o singură medalie de bronz la bobul de două persoane, la Grenoble, în 1968) au avut performanțe, vârfurile fiind gimnastica, atletismul, canotajul.

Rândurile de față își propun să fie o sinteză a ideii despre cultura, antisemitism şi Holocaust în totalitarism, precum și supraviețuirea acestor forme până în epoca contemporană, sfârșind prin a se întrepătrunde din punct de vedere semantic.

\section{BIBLIOGRAFIE:}

- Browning, Christopher R., The Origins of the Final Solution:The Evolution of Nazi Jewish Policy, September 1939 - March 1942. Comprehensive History of the Holocaust. Lincoln, University of Nebraska Press, 2004.

- Cătănuş, Dan, Roske, Octavian, Colectivizarea agriculturii. Represiunea, vol. I, 1949 - 1953, INST, 2004

- Eminescu, Gheorghe, Napoleon Bonaparte, Editura Eminescu, București, 1986.

- Johnson, Paul, O istorie a evreilor, București, Editura Humanitas, 2015.

- Maur, M. Istoria Israelului din preistorie până după războiul de şase zile, Oradea, Editura Aion, 2000.

- Rayman, Paula, The Kibbutz Community and Nation Building. Princeton University Press, 1981.

- Olteanu, Florian, Zamfirescu, Carmen, Nacu, Florin, Stoica, Vasile, Tiranie, dictatură și revoluție, Editura Aius, Craiova, 2013.

- Olteanu, Florian, Zamfirescu, Carmen, Nacu, Florin, România pe muchie de cuțit, Editura Aius, Craiova, 2014.

- Olteanu, Florian, Zamfirescu, Carmen, Cafeneaua Coanei Europa, Craiova, Editura Revers, 2014.

- Olteanu, Florian, Zamfirescu, Carmen, Cafeneaua Coanei Europa, Vol. II, București, Editura Digitală, 2015.

- Olteanu, Florian, Amon, Lucian, La tyrannie grecque. Implications historiques, sociales et politiques (La Grece Insulaire et l'Asie Mineure), în Istorie şi societate (editor Gh. Buzatu), Editura Mica Valahie, Bucureşti, 2004, p.509-514.

- Schmitt, Oliver Jens, Corneliu Zelea Codreanu. Ascensiunea și căderea "Căpitanului", Editura Humanitas, Bucureșt, 2017.

- Zamfirescu Carmen, Olteanu, Florian, Drogurile $\neg$ expresia terorismului alb $\urcorner$ - pro-filul unei ameninţări globale, Editura Grafix, Craiova, 2015. 